\title{
PROFIL PENALARAN KUANTITATIF DAN KEMAMPUAN GENERALISASI SISWA PADA MATERI PERBANDINGAN SENILAI
}

\author{
Muhammad Muzaini ${ }^{1}$ \\ Program Studi Pendidikan Matematika ${ }^{1}$, Fakultas Keguruan dan Ilmu \\ Pendidikan $^{1}$, Universitas Cokroaminoto Palopo ${ }^{1}$ \\ ucha.2610@gmail.com ${ }^{1}$
}

\begin{abstract}
Abstrak
Penelitian ini merupakan penelitian kualitatif yang bertujuan untuk untuk mendeskripsikan penalaran kuantitatif dan kemampuan menggeneralisasi siswa. Penelitian ini melibatkan 125 siswa kelas VIII SMP. salah satunya dengan keterampilan sedang dipilih sebagai subjek utama. Data dikumpulkan melalui tes, tugas, dan wawancara berbasis tugas. Hasil penelitian ini menunjukkan bahwa generalisasi yang dibangun oleh subjek diawali dengan membentuk hubungan antara dua atau lebih kuantitas dengan membangun rasio dari kuantitas yang muncul yang menghubungkan dua kuantitas awal, mengulangi tindakan untuk menemukan elemen kesamaan dan kemudian mengembangkan pola atau relasi ke dalam bentuk struktur yang lebih umum. Sehingga Penalaran kuantitatif yang dimiliki subjek sangat mempengaruhi generalisasi yang dilakukan. Hasil penelitian ini penting sebagai bahan masukan bagi guru, untuk mengembangkan generalisasi yang kuat secara umum, maka siswa harus membangun rasio dari kuantitas yang muncul dengan menghubungkan antar kuantitas. Sehingga dapat mendukung kemampuan siswa untuk melakukan generalisasi dengan benar.
\end{abstract}

Kata Kunci: Penalaran Kuantitatif, Generalisasi Perbandingan senilai.

\section{A. Pendahuluan}

Penalaran kuantitatif memiliki peran yang sangat penting dalam proses generalisasi siswa (Dorko, A., \& Weber, E, 2014). Penalaran kuantitatif telah didefinisikan sebagai mengidentifikasi kuantitas, membangun kuantitas baru, serta merepresentasikan hubungan antar kuantitas (Moore, Carlson, \& Oehrtman 2009; Thompson, 2011). Penalaran kuantitatif mengacu pada cara berpikir yang menekankan pada perkembangan kognitif siswa dari objek konseptual yang mereka pikirkan mengenai situasi matematika (Smith III \& Thompson, 2008; Thompson, 1989). Penalaran kuantitatif berfokus pada tindakan mental seorang siswa dalam memahami situasi yang dihadapi, membangun kuantitas, menghubungkan, memanipulasi, dan menggunakan kuantitas tersebut untuk membuat masalah menjadi layak. 


\section{Profil Penalaran Kuantitatif Dan Kemampuan Generalisasi Siswa Pada Materi Perbandingan Senilai}

Thompson (1990, p.13) memandang bahwa penalaran kuantitatif itu sebagai analisis situasi menjadi suatu struktur berupa jaringan kuantitas-kuantitas dan hubungan kuantitatif. Struktur kuantitatif yang dimaksud adalah jaringan hubungan-hubungan kuantitatif. Hubungan kuantitatif tersebut berupa konsepsi tiga kuantitas, dua diantaranya menentukan kuantitas ketiga dengan menggunakan operasi kuantitatif (Moore, Carlson, \& Oehrtman, 2009). Seperti satu kuantitas dapat berhubung dengan kuantitas lain, contohnya kecepatan adalah kuantitas yang berhubungan dengan kuantitas jarak dan waktu. Pada aktivitas generalisasi, siswa berpikir untuk mengubah kuantitas berdasarkan suatu aktivitas yang dilakukan (Carraher et al. 2008). Artinya seseorang akan mencoba menemukan aturan yang mengubah bilangan-bilangan tertentu dan melihat kembali apakah aturan tersebut berlaku jika digunakan dalam konteks yang lebih luas.

Profil penalaran kuantitatif dalam penelitian ini adalah deskripsi alami dan utuh tentang cara yang digunakan seseorang untuk mengambarkan aktivitas mental dalam menganalisis kuantitas, menghubungkan kuantitas yang terdapat dalam situasi, dan menentukan kemampuan dan prosedur yang digunakan untuk menyelesaikan permasalahan tertentu untuk sampai pada suatu kesimpulan. Kemampuan generalisasi dengan fokus pada penalaran kuantitatif dilihat melalui karakterisasi yang disusun oleh Ellis (2007). Tiga karakterisasi tindakan generalisasi tersebut yaitu: Tipe 1: Relating, Tipe 2: Searching, dan Tipe 3: Extending. Tipe relating didefenisikan sebagai membentuk hubungan antara dua atau lebih masalah atau kuantitas, tipe searching didefenisikan sebagai mengulangi tindakan untuk menemukan elemen kesamaan dan tipe extending didefinisikan mengembangkan pola atau relasi ke dalam struktur yang lebih umum.

Profil penalaran kuantitatif dan kemampuan generalisasi pada karakteristik relating dapat diamati melalui aspek bagaimana seseorang menyebutkan masalah yang mirip yang pernah diperoleh sebelumnya dengan masalah yang diberikan dan menyebutkan hubungan antar kuantitas-kuantitas; karakteristik searching diamati melalui aspek bagaimana seseorang melakukan tindakan secara berulang untuk mendeteksi hubungan yang tetap antara dua kuantitas atau lebih, Secara berulang melakukan prosedur untuk mendeteksi hubungan, mendeteksi pola yang sama pada masalah/situasi yang diberikan dan bagaimana seseorang mencari solusi atau hasil 
yang sama; dan karakteristik yang terakhir yaitu extending diamati melalui aspek menjelaskan bagaimana seseorang memperoleh persamaan sehingga persamaan tersebut bisa diterapkan untuk semua masalah dalam situasi dan menyebutkan situasi baru berdasarkan situasi yang diberikan.

\section{B. Metode Penelitian}

Metode penelitian menjelaskan rancangan kegiatan, ruang lingkup atau objek, bahan dan alat penelitian, tempat, teknik pengumpulan data, definisi operasional variable penelitian, dan teknik analisis.

Penelitian ini adalah penelitian kualitatif. Pengumpulan data dimulai dengan memberikan tes kemampuan matematika kepada 35 siswa SMPN 1 Pangkaje'ne Kab. Pankep. Hasil dari tes ini digunakan untuk mengkategorikan siswa berdasarkan tingkat kemampuan matematika mereka. Selanjutnya, peneliti melakukan tes dengan memberikan tugas penalaran kuantitatif kepada 35 siswa, tes penalaran kuantitatif yang diberikan berupa masalah Matematika yang berkaitan dengan materi perbandingan senilai. Soal tes penalaran kuantitif yang diberikan sebagai berikut:

Sebuah toko kue tradisional Makassar untuk memproduksi 12 bungkus kue barongko yang enak dan nikmat, membutuhkan jenis bahan-bahan sebagai berikut.

\begin{tabular}{lll} 
No & \multicolumn{1}{c}{ Bahan } & \multicolumn{1}{c}{ Takaran } \\
1. & Pisang Kepok & 10 biji \\
\hline 2. & Telur & 6 butir \\
\hline 3. & Gula Pasir & 300 gram \\
\hline 4. & Santan Kental & $250 \mathrm{ml}$ \\
\hline
\end{tabular}

a. Jika pemilik toko kue tersebut hendak membuat 18 bungkus kue barongko dengan kualitas dan jenis bahan yang sama di atas, tentukan bahan-bahan yang dibutuhkan? Jelaskan!

b. Tentukan banyaknya santan kental yang dibutuhkan jika akan dibuat 25 bungkus kue barongko?

c. Jika pemilik toko ingin membuat kue dengan 10 butir telur, berapa kue yang bisa dibuat dan tentukan bahan lain yang dibutuhkan?

d. Tentukan banyaknya pisang, telur, gula pasir dan santan kental jika akan dibuat masing-masing 24 bungkus kue barongko, 48 bungkus kue barongko dan 96 bungkus kue barongko?

e. Tentukan banyaknya pisang kepok, telur, gula pasir dan santan kental jika akan dibuat $n$-kue barongko? 


\section{Profil Penalaran Kuantitatif Dan Kemampuan Generalisasi Siswa Pada Materi \\ Perbandingan Senilai}

Berdasarkan hasil analisis, peneliti memilih satu dari 35 siswa dengan keterampilan matematika sedang sebagai subjek penelitian. Penentuan ini didasarkan pada pertimbangan bahwa Penalaran kuantitatif dan kemampuan menggeneralisasi siswa dengan keterampilan matematika sedang setidaknya dapat memberikan gambaran umum untuk dua kelompok lainnya. Pada tahap berikutnya, subjek penelitian diberi TPK I yang berisi kasus bagaimana subjek memanfaatkan penalaran kuantitatif dan kemampuan generalisasi mereka. Selain itu, untuk melihat penalaran kuantiatatif dan kemampuan generalisasi subjek, peneliti juga memberikan tugas yang sama kepada 34 siswa lainnya pada kelas yang sama. Hasil kerja subjek pada TPK I kemudian dianalisis berdasarkan kerangka teoritis penalaran kuantitatif dan tahapan-tahapan generalisasi yang telah disiapkan. Selain itu, peneliti juga melakukan wawancara berdasarkan karya subjek. Sedangkan karya 34 siswa lainnya dianalisis untuk mendapatkan gambaran umum tentang penalaran kuantitatif dan kemampuan generelasiasi yang mereka buat. Selanjutnya, peneliti melakukan triangulasi data dengan memberikan Tugas TPK II yang mirip dengan Tugas TPK I. sehingga saya mendapatkan data yang valid tentang penalaran kuantitatif dan kemampuan generalisasi mereka. Hasil dari pekerjaan ini kemudian dianalisis dan digunakan sebagai dasar untuk mewawancarai subjek. Hasil analisis pada tahap pertama dan kedua kemudian dibandingkan untuk memperoleh data akhir deskripsi penalaran kuantitatif dan kemampuan mereka dalam menggeneralisasi.

\section{Hasil Dan Pembahasan}

\section{Gambaran Kemampuan Matematika Siswa Dalam Menggeneralisasi}

TPK I diselesaiakn oleh 35 siswa. TPK I yang diberikan terdiri dari 5 kasus, dimana secara umum kasus tersebut untuk melihat penalaran kuantitatif dan kemampuan generalisasi siswa.

Berdasarkan hasil analisis, ditemukan 16 siswa $(45,7 \%)$ yang bisa melakukan generalisasi dengan benar; 12 siswa $(34,3 \%)$ dapat menyelesaikan dengan benar, akan tetapi tidak sampai pada proses generalisasi dan membuat berbagai kesalahan baik konseptual maupun prosedural dalam proses penyelesainnya. Sementara ada 7 siswa (20\%) tidak bisa menyelesaikan sepenuhnya, mereka terkendala pada konsep atau strategi apa yang akan mereka gunakan. Sebagian besar dari mereka, menalara 
kuantitas yang ada dengan menggunakan konsep perbandingan untuk menyelesaikan kasus tersebut. kesalahan paling umum yaitu gagal dalam melakukan generalisasi atau mencari bentuk umum.

\section{Deskripsi Penalan Kuantitatif Siswa Pada Tahap Menghubungkan (Relating)}

Berdasarkan analisis mendalam setelah diberikan tugas penalaran kuantitatif (TPK I) ditemukan beberapa kegiatan menghubungkan yang dilakukan oleh subjek. Pertama yaitu membangun hubungan kesamaan antara dua atau lebih masalah atau kuantitas, dimana subjek menghubungkan situasi masalah dengan masalah yang diperoleh sebelumnya. Seperti situasi pada TPK I yaitu situasi produksi kue barongko dengan bahan-bahan yang dibutuhkan. Kemudian Subjek mengungkapkan masalah atau situasi yang mirip seperti masalah yang dihadapi, masalahnya terkait dengan masalah kehidupan sehari-hari.

\begin{tabular}{ll}
\hline \multicolumn{1}{c}{ P/S } & \multicolumn{1}{c}{ Isi Wawancara Percakapan } \\
\hline Peneliti & $\begin{array}{l}\text { Coba perhatikan soal TPK I yang kamu hadapi, pernahkah kamu melihat soal yang mirip } \\
\text { dengan soal itu sebelumnya? }\end{array}$ \\
Subjek & Pernah \\
Peneliti & Apakah kamu masih ingat dengan soalnya? \\
Subjek & Masih \\
Peneliti & Bisa kamu menyebutkan soalnya? \\
Subjek $i$ & Misalnya sebuah kendaraan bermotor memerlukan 10 liter bensin untuk menempuh jarak \\
& 400 km. tentukan berapa liter bensin yang diperlukan untuk menempuh jarak 600 km? \\
$:$ & \\
$:$ & Selanjutnya, Setelah kamu membaca soal hubungan-hubungan apa saja yang kamu \\
Peneliti & temukan?jelaskan hubungannya seperti apa? \\
Subjek & Seperti sebuah toko kue tradisional memproduksi 12 bungkus kue barongko membutuhkan \\
& bahan-bahan yang ini (menunjuk tabel bahan-bahan pada soal) \\
Peneliti & Hubungannya yang mana? \\
Subjek & Untuk membuat 12 bungkus kue membutuhkan bahan-bahan yang ini (menunjuk tabel \\
& bahan-bahan pada soal) \\
Peneliti & Ada hubungan yang lain? \\
Subjek & Perbandingan antar bahan, pisang kepok dengan telur 10 banding 6 sama dengan 5 banding \\
& 3, pisang kepok banding gula pasir 10 banding 300 atau 1 banding 30 seperti itu. \\
\hline
\end{tabular}

Dari hasil analisis dan wawancara di atas tampak bahwa subjek umumnya mampu menghubungkan pemahamannya terkait situasi produksi kue dan bahan-bahan yang dibutuhkan dengan mengungkapkan situasi yang mirip dengan situasi yang diberikan, dimana situasi tersebut berkaitan dengan kehidupan sehari-hari. Selanjutnya Subjek menalar kuantitas kue dengan kuantitas bahan-bahan yang dibutuhkan, dan membuat hubungan antara kuantitas bahan. Dari hasil pemahamannya, subjek mengungkapkan bahwa semakin banyak kue yang 
diproduksi akan membutuhkan bahan-bahan lebih banyak dan begitupun sebaliknya.

\section{Deskripsi Penalan Kuantitatif Siswa Pada Tahap Mencari (Searching)}

Ada beberapa aspek yang dilakukan oleh subjek pada tahap mencari. Pertama, hasil analisis menunjukkan, subjek melakukan tindakan secara berulang untuk mendeteksi hubungan yang tetap antara dua kuantitas atau lebih, dengan mengidentifikasi adanya hubungan yang tetap antar kuantitas bahan untuk membuat 12 bungkus kue barongko. Selanjutnya ia membuat rasio untuk menalar kuantitas yang muncul dengan cara membandingkan antar kuantitas bahan. Subjek juga mengungkapkan bahwa untuk membuat 12 bungkus kue barongko rasio perbandingan antara pisang kepok dan telur adalah $5: 3$, pisang kepok dan gula pasir 1 : 30 dst, dan kemudian meyakinkan bahwa perbandingan ini akan tetap stabil/tetap, untuk berapun kue yang akan dibuat.

\begin{tabular}{|c|c|}
\hline & Isi Wawancara Percakapan \\
\hline Peneliti & $\begin{array}{l}\text { Kamu mengatakan bahwa ada hubungan antar bahan, dimana untuk } \\
\text { membuat } 12 \text { bungkus kue barongko memiliki perbandingan pisang kepok } \\
\text { dan telur itu } 10 \text { banding } 6 \text { atau } 5 \text { banding } 3 \text {. }\end{array}$ \\
\hline Subjek & Iyaa \\
\hline Peneliti & $\begin{array}{l}\text { Jika pemilik toko ingin membuat } 18,20,40 \text { kue barongko, berapa } \\
\text { perbandingan antara pisang kepok dan telur? }\end{array}$ \\
\hline Subjek & Sama atau tetap yaitu 5 banding 3 \\
\hline Peneliti & Kenapa bisa sama? \\
\hline Subjek & Harus sama perbandingannya agar kuenya terasa enak dan nikmat. \\
\hline
\end{tabular}

Kegiatan kedua mencari prosedur yang sama untuk menganalisis hubungan antara kuantitas. Kemudian diberikan pertanyaan "Berapa banyak bahan yang dibutuhkan oleh pemilik untuk membuat 18 bungkus kue barongko dengan kualitas dan bahan yang sama? Jelaskan!". Pertama, subjek mencari kuantitas kue dan kuantitas bahan untuk menemukan hubungan. Kedua, subjek membandingkan kuantitas tersebut untuk menemukan rasio untuk membuat satu bungkus kue barongko. Selanjutnya, untuk mencari solusi, subjek secara prosedural melakukan perkalian antara kuantitas kue yang dibuat (18 bungkus) dengan kuantitas bahan. Berdasarkan hasil analisis, Subjek menggunakan penalaran kuantitatifnya untuk menyelesaikan masalah matematika yang dihadapi.

Kegiatan ketiga mencari pola. Subjek mengidentifikasi hubungan antara kuantitas kue barongko dan kuantitas bahan-bahan yang dibutuhkan, dan kemudian digeneralisasikan untuk menemukan pola yang sama. Pola yang diperoleh dikenal 
sebagai pola rekursif, yaitu setiap kue bertambah 2 kali lipat, 4 kali lipat, dan 8 kali lipat maka bahan juga akan bertambah 2 kali lipat, 4 kali lipat dan 8 kali lipat. Jadi, subjek menyimpulkan dengan memberikan pendapat bahwa, jika kue meningkat jumlah bahan akan meningkat juga dan pola ini akan tetap stabil. Dapat dilihat pada jawaban subjek pada Gambar 1 di bawah ini:

D.
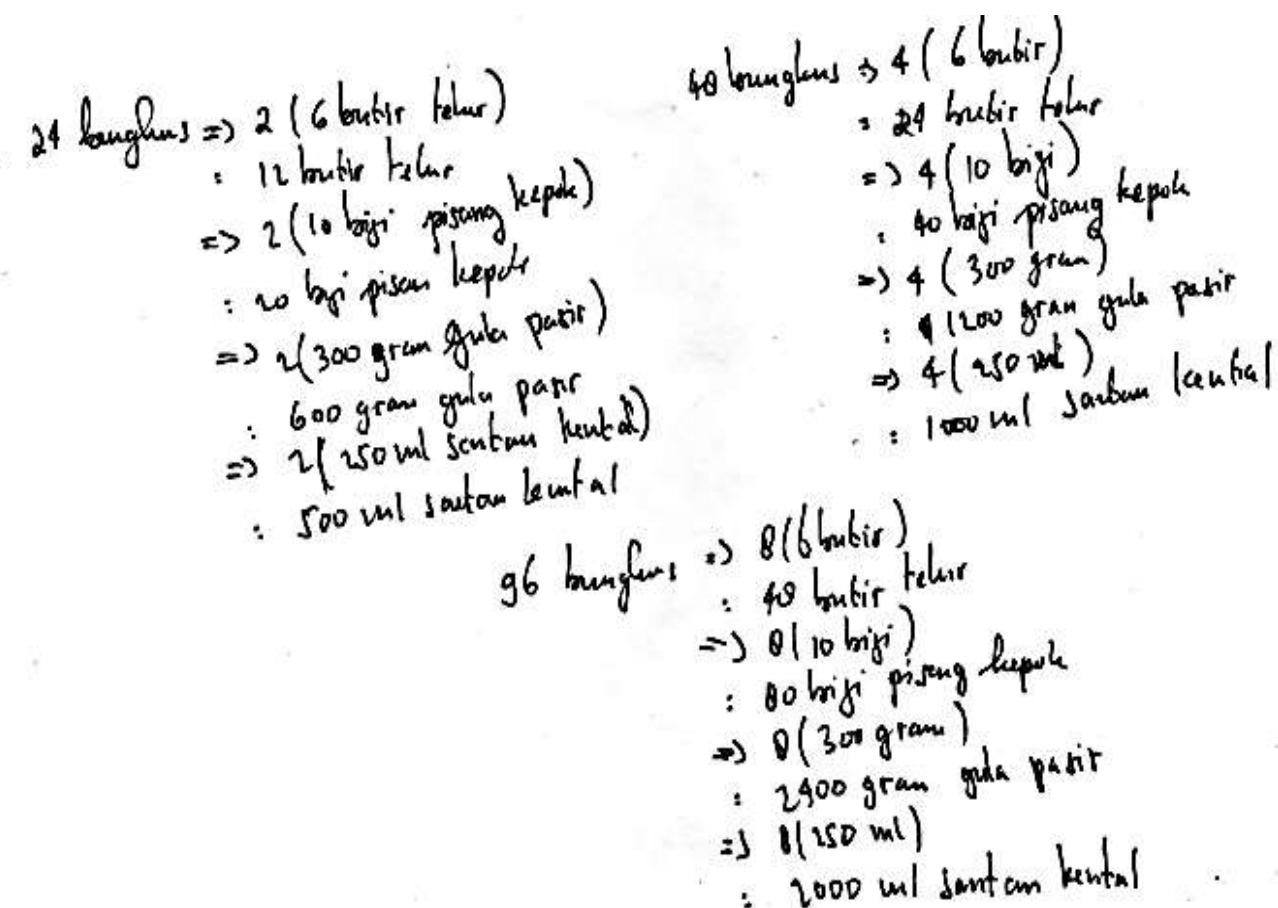

Gambar 1: Jawaban subjek pada aktivitas mencari (searching)

\section{Deskripsi Penalan Kuantitatif Siswa Pada Tahap Memperluas Temuan (extending)}

Berdasarkan hasil analisis pada tahap memperluas temuan, generalisasi yang mereka bangun didasari pada aktifitas mencari hubungan, seperti subjek menalar kuantitas dengan rasio kue (18 bungkus kue barongko) dan bahan-bahan yang dibutuhkan untuk memperoleh kuantitas bahan yang dibutuhkan untuk membuat satu bungkus kue barongko yang dihasilkan. Dari hasil yang diperoleh subjek bisa memperluas temuannya, seperti yang diungkapkan subjek, untuk mencari berapa banyak bahan yang digunakan untuk membuat $n$-kue, subjek secara prosedural mengalikan $n$-kue tersebut dengan bahan-bahan yang telah diperoleh untuk membuat satu bungkus kue barongko. Ini bisa dilihat dari hasil jawaban subjek di bawah ini: 


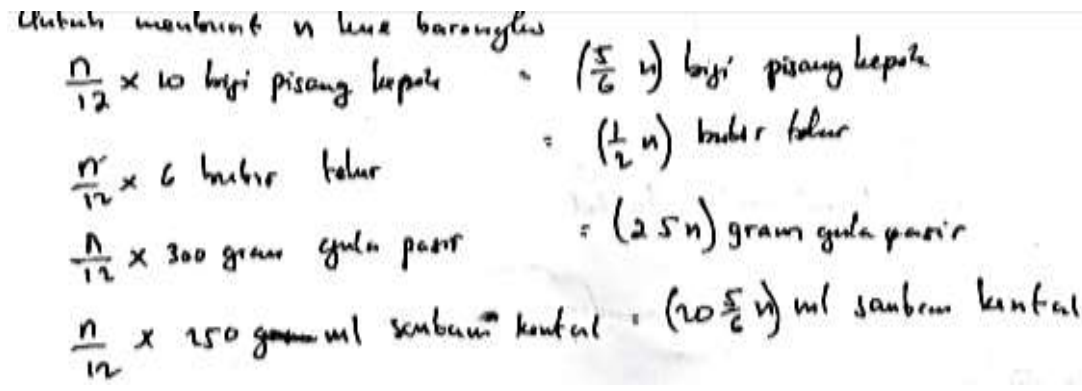

Gambar 2: Jawaban subjek menemukan bentuk umum

Selanjutnya ada aktifitas lain yang terlihat yaitu subjek tidak hanya fokus pada hubungan akan tetapi juga fokus pada pola bilangan, ini tergambar dari hasil pekerjaan yang dilakukan subjek pada kasus TPK I bagian d. ketika subjek fokus pada bilangan mengakibatkan generalisasi yang dibentuk akan selalu terkait pada bilangan yang mereka hadapi. Misalnya, subjek diminta untuk menentukan bahanbahan yang digunakan untuk membuat 24, 48 dan 96 bungkus kue barongko. subjek menemukan ada pola rekursif yaitu setiap kue bertambah 2 kali lipat, 4 kali lipat, dan 8 kali lipat maka bahan juga akan bertambah 2 kali lipat, 4 kali lipat dan 8 kali lipat. Pertanyaan lanjutan yang diberikan kepada subjek yaitu berapa bahan-bahan yang dibutuhkan jika akan dibuat 192 kue barongko?. Secara matematis untuk memperoleh bahan-bahan yang digunakan untuk membuat 192 bungkus kue barongko subjek membagi 192 dengan 12 lalu hasil bagi tersebut dikali dengan bahan-bahan yang diketahui. Ini merupakan contoh baru yang dihasilkan dari generalisasi yang fokus pada pola bilangan dengan mengulangi pola yang ada.

Pada tahap mengaplikasikan untuk situasi baru, peneliti memberikan pertanyaan “Dari soal yang kamu hadapi, bisakah kamu membuat soal yang mirip dengan soal ini?. Subjek mengetahui bahwa soal yang dihadapi merupakan soal yang dialami dalam kehidupan sehari-hari, maka subjek mengungkapkan dan menuliskan soal yang mirip dengan soal yang ia hadapi tersebut. subjek juga menjelaskan kemiripan soal tersebut adalah proses penyelesainnya sama, konsep dan materi yang digunakan sama. Berikut adalah tabel ringkasan hasil penalaran kuantitatif dalam menggeneralisasi yang dihasilkan subjek: 


\begin{tabular}{|c|c|}
\hline Tipe Generalisasi & $\begin{array}{c}\text { Aktivitas Penalaran Kuantitatif dalam Menggeneralisasi } \\
\text { yang dihasilkan Subjek }\end{array}$ \\
\hline $\begin{array}{l}\text { Menghubungkan } \\
\text { (Relating) }\end{array}$ & $\begin{array}{l}\text { - Subjek mengungkapkan masalah atau situasi yang mirip } \\
\text { seperti masalah yang dihadapi, masalahnya terkait dengan } \\
\text { masalah dalam kehidupan sehari-hari. } \\
\text { - Subjek membuat hubungan antar kuantitas kue (12 bungkus } \\
\text { kue) dengan kuantitas bahan dan hubungan antar kuantitas } \\
\text { bahan. }\end{array}$ \\
\hline $\begin{array}{l}\text { Mencari } \\
\text { (Searching) }\end{array}$ & $\begin{array}{l}\text { - Menemukan hubungan yang tetap yaitu hubungan antar bahan. } \\
\text { Hubungan tetap yang dimaksud adalah hubungan } \\
\text { perbandingan antar bahan dalam memproduksi kue barongko. } \\
\text { - Dalam mencari prosedur subjek menggunakan penalaran } \\
\text { kuantitatifnya dengan mencari hubungan antar kuantitas } \\
\text { kemudian melaksanakan perhitungan yang fokus pada } \\
\text { kuantitas dan hubungan antara kuantitas untuk sampai pada } \\
\text { solusi atau hasil yang diperoleh. } \\
\text { - Melihat adanya pola yaitu pola rekursif } \\
\text { - Mendapatkan solusi } \\
\text { - Melakukan validasi dari solusi masalah yang telah diperoleh }\end{array}$ \\
\hline $\begin{array}{l}\text { Memperluas } \\
\text { Temuan } \\
\text { (Extending) }\end{array}$ & $\begin{array}{l}\text { - Mendapatkan persamaan umum. } \\
\text { - Menggunakan bentuk umum untuk memvalidasi solusi yang } \\
\text { dihasilkan } \\
\text { - Megungkapkan situasi baru yang mirip berdasarkan situasi } \\
\text { yang diberikan (situasi dunia nyata) }\end{array}$ \\
\hline
\end{tabular}

Ini sejalan dengan pendapat, Muzaini, M., dkk (2019), Ellis, A. (2007), Lobato, J., \& Siebert, D. (2002) dan Hall, R., \& Rubin, A. (1998) yaitu memberikan situasi yang kaya secara kuantitatif menunjukkan bahwa subjek dapat membuat hubungan, melihat pola, mengidentifikasi hubungan, dan membuat generalisasi yang semuanya memiliki makna kuantitatif.

\section{Kesimpulan}

Penelitian mengungkapkan bahwa profil penalaran kuantitatif dan kemampuan generalisasi siswa pada tipe menghubungkan (relating) yaitu Subjek dapat mengungkapkan masalah atau situasi yang mirip seperti masalah yang dihadapi dan subjek menggunakan penalaran kuantitatifnya seperti membuat hubungan antar kuantitas kue (12 bungkus kue) dengan kuantitas bahan dan hubungan antar kuantitas bahan. Pada tipe mencari (searching) subjek juga telah menggunakan penalaran kuantitatifnya dengan menemukan hubungan yang tetap yaitu hubungan antar bahan. Dalam mencari prosedur subjek menggunakan penalaran kuantitatifnya untuk mencari hubungan antar kuantitas kemudian melaksanakan perhitungan yang fokus pada kuantitas dan hubungan antara kuantitas untuk sampai pada solusi atau hasil yang diperoleh. kemudian subjek melihat adanya pola rekursif, dan mendapatkan solusi. Pada tipe yang terakhir yaitu tipe memperluas temuan (extending) subjek melakukan tindakan yang berulang untuk mendapatkan 
persamaan umum. Dapat megungkapkan situasi baru yang mirip berdasarkan situasi yang diberikan (situasi dunia nyata). Subjek yang menggunakan penalaran kuantitatifnya memberikan bukti generalisasi yang dilakukan lebih efektif, menciptakan kesimpulan yang benar, dan menghasilkan klaim pembenaran yang tepat. Penggunaan penalaran kuantitatif dapat membantu siswa fokus pada kuantitas dan hubungan kuantitatif untuk menghasilkan generalisasi yang benar, kuat, dan terhubung dengan pengetahuan lainnya.

\section{Daftar Pustaka}

Carlson, M. P., Oehrtman, M., \& Thompson, P. 2009 Foundational reasoning abilities that Promote coherence in students' understanding of function. In M. P. Carlson \& C. Rasmussen (Eds.), making the connection: Research and practice in undergraduate mathematics Washington, DC: Mathematical Association of America. p. 150-171.

Carraher, D. W., Martinez, M.V., \& Schliemann, A.D. 2008 Early Algebra and Mathematical Generalitation. ZDM Mathematics Educational Journal (2008). 40, DOI: 10.1007/s11858-007-0067-7. p. 3-22.

Dorko, A., \& Weber, E. (2014). Generalising calculus ideas from two dimensions to three: How multivariable calculus students think about domain and range. Research in Mathematics Education, 16(3), 269-287.

Ellis, A. 2007a Connections between generalizing and justifying: Students' reasoning with Linear relationships. Journal for Research in Mathematics Education, 38(3), p 194-229.

Ellis, A. 2007b A taxonomy for categorizing generalizations: Generalizing actions and Reflection generalizations. The Journal of Learning Sciences, 16(2), p. 221-262.

Hall, R., \& Rubin, A. 1998 There's five little notches in here: dilemmas in teaching and Learning the conventional structure of rate. In J. Greeno \& S. Goldman (Eds), Thinking Practices in mathematics and science learning.. Mahwah, NJ: Lawrence Erlbaum Associates. p. 189-236.

Lobato, J., \& Siebert, D. 2002 Quantitative reasoning in a reconceived view of transfer. Journal of Mathematical Behaviour, 21, p. 87-116.

Moore, K., Carlson, M., \& Oehrtman, M. 2009 The Role of Quantitative Reasoning in Solving Applied Precalculus Problems, Proceedings of the Twelfth Conference on Research In Undergraduate Mathematics Education, 26 pages, Web publication at.

Muzaini, M., Juniati, D., \& Siswono, T. Y. (2018). Cognitive Style of Filedependent (FD): Quantitative Reasoning in Generalizing. Pancaran Pendidikan, 7(1). 
Muzaini, M., Juniati, D., \& Siswono, T. Y. E. (2019, February). Exploration of student's quantitative reasoning in solving mathematical problem: case study of field-dependent cognitive style. In Journal of Physics: Conference Series (Vol. 1157, No. 3, p. 032093). IOP Publishing.

Smith III, J., \& Thompson, P. 2008 Quantitative reasoning and the development of algebraic Reasoning. In J. J. Kaput \& M. Blanton (Eds.), Algebra in the Early Grades. New York, NY: Lawrence Erlbaum Associates. p. 95-132

Thompson, P. 2011 Quantitative reasoning and mathematical modeling. In L. L. Hatfield, S. Chamberlain \& S. Belbase (Eds.), New perspectives and directions for collaborative Research in mathematics education. Laramie, WY: University of Wyoming. p. 33-57

Thompson, P.W. 1990 A Theoretical Model of Quantity-Based Reasoning in Arithmetic and Algebra. Paper presented at the Annual Meeting of the American Educational Research Association, San Fransisco, March 27-31, 1989.

Thompson, P. 1989 A cognitive model of quantity-based algebraic reasoning. Paper presented At the Annual Meeting of the American Educational Research Association. 